\title{
RADIONUCLIDE CHARACTERISTICS OF RDE SPENT FUELS
}

\author{
Ihda Husnayani, Pande Made Udiyani \\ Center for Nuclear Reactor Technology and Safety (PTKRN) - BATAN \\ Puspiptek Complex, no. 80, Tangerang Selatan, 15310 \\ Diterima editor: 6 Februari 2018 \\ Diperbaiki: 28 Maret 2018 \\ Disetujui untuk publikasi: 28 Maret 2018
}

\begin{abstract}
RADIONUCLIDE CHARACTERISTICS OF RDE SPENT FUELS. Reaktor Daya Eksperimental (RDE) is a 10 MWth pebble-bed High Temperature Gas-cooled Reactor that is planned to be constructed by National Nuclear Energy Agency of Indonesia (BATAN) in Puspiptek complex, Tangerang Selatan. $\mathrm{RDE}$ utilizes low enriched $\mathrm{UO}_{2}$ fuel coated by TRISO layers and loaded into the core by means of multipass loading scheme. Determination of radionuclide characteristics of RDE spent fuel; such as activity, thermal power, neutron and photon release rates; are very important because those characteristics are crucial to be used as a base for evaluating the safety of spent fuel handling system and storage tank. This study is aimed to investigate the radionuclide characteristics of RDE spent fuel at the end of cycle and during the first 5 years cooling time in spent fuel storage. The method used to investigate the radionuclide characteristics is burnup calculation using ORIGEN2.1 code. In performing the ORIGEN2.1 calculation, one pebble fuel was assumed to be irradiated in the core for 5 cycles and then decayed for 5 years. At the end of the fifth cycle, it is obtained that the total activity, thermal power, neutron production, and photon release rates from all radionuclides inside one spent fuel are approximately 105.68 curies, 0.41 watts, $2.65 \times 10^{3}$ neutrons/second, and $1.79 \times 10^{4}$ photons/second, respectively. The results for the radionuclides characteristics during the first 5 years cooling time in the spent fuel storage show that the radioactivity characteristics from all radionuclides are rapidly decreasing at the first year and then slowly decreasing at the second until the fifth year of cooling time. The results obtained in this study can provide data for safety evaluation of fuel handling and spent fuel storage, such as the calculation of sourceterm, radiation dose rate, and the determination of radiation shielding.
\end{abstract}

Keywords: RDE, spent fuel, radionuclide activity, thermal power, neutron production, photon releaserates

\section{ABSTRAK}

KARAKTERISTIK RADIONUKLIDA DI DALAM BAHAN BAKAR RDE. Reaktor Daya Eksperimental (RDE) adalah reaktor tipe Reaktor Temperatur Tinggi Berpendingin Gas dengan daya termal 10MW yang akan dibangun oleh BadanTenagaNuklirNasional (BATAN) di kawasanPuspiptek, Tangerang Selatan. RDE menggunakan bahan bakar $\mathrm{UO}_{2}$ yang dilapisi dengan lapisan TRISO dan dimasukkan ke dalam teras RDE menurut skema multipass (5 siklus). Penentuan karakteristik radionuklida di dalam bahan bakar RDE; seperti aktivitas, daya termal, laju produksi neutron dan pelepasan foton; adalah sangat penting karena informasi karakteristik ini diperlukan sebagai dasar untuk melakukan evaluasi keselamatan system penanganan dan penyimpanan bahan bakar bekas. Penelitian ini bertujuan untuk menganalisis karakteristik radionuklida bahanbakar RDE setelah 5 siklus dan pada 5 tahun pertama pendinginan ditempat penyimpanan bahan bakar bekas. Metode yang digunakan dalam menghitung karakteristik radionuklida adalah menggunakan program ORIGEN2.1. Satu bola bahan bakar RDE diasumsikan diiradiasi selama 5 siklus dan kemudian meluruh selama 5 tahun. Pada akhir siklus, diperoleh hasil aktivitas total, daya termal, laju produksi neutron dan pelepasan foton dari seluruh radionuklida di dalam satu bola bahan bakar RDE sebesar 105,68 curies, 0,41 watts, 2,65 $\times 10^{3}$ neutron/detik, dan 1,79 $\times 10^{4}$ foton/detik. Hasil untuk karakteristik radionuklida selama 5 tahun penyimpanan menunjukkan bahwa karakteristik radioktivitas radionuklida menurun dengan cepat pada tahun pertama dan kemudian menurun lebih lambat pada tahun kedua hingga tahun kelima. Hasil perhitungan karakteristik radionuklida dari penelitian ini dapat digunakan sebagai basis untuk analisis keselamatan penanganan dan penyimpanan bahan bakarbekas RDE.

Kata kunci:RDE, bahan bakar bekas, aktivitas radionuklida, daya termal, produksi neutron, laju foton

DOI: $\underline{10.17146 / \mathrm{tdm} .2018 .20 .2 .4101}$ 


\section{INTRODUCTION}

Reaktor Daya Eksperimental (RDE) is a 10 MWth pebble-bed type High Temperature Gascooled Reactor (HTGR) which is planned to be built by National Nuclear Energy Agency of Indonesia (BATAN) in Puspiptek Complex, Tangerang Selatan [1]. RDE belongs to the generation-IV reactor, which is a category for advance reactor and expected to be a solution to some remaining concerns of conventional power reactor regarding the sustainability, economic viability, safety, reliability, and proliferation resistance [2]. RDE is a very attractive solution to the electiricity and heat demand in Indonesia [3]. The design of RDE is adopted from the HTR-10. HTR-10 is a pebble bed HTGR developed by Institute of Nuclear and New Energy (INET), Tsinghua University, China [4].

One of the unique aspects of RDE design is its fuel type which is a solid spherical graphite containing thousands of microkernels uranium coated by ceramic materials (Inner Pyrolitic Carbon, Silicon Carbide, Outer Pyrolitic Carbon), which is known as fuel pebble. The fuel pebbles are loaded into the core on the multipass loading scheme for 5 cycles. The burnup of each fuel pebble will be measured at the end of each cycle and pebble that has reached the target burnup will be discharged out of the core and moved into the spent fuel storage.

This study is aimed to investigate the radionuclide characteristics of RDE fuel pebble at the end of 5 cycles and after 5 years cooling time in the spent fuel storage. Those radionuclide characteristics are activity, thermal power, neutron production rates, and photon release rates. The knowledge of radionuclide characteristics of spent fuel is very important for evaluating the safety of fuel handling system and spent fuel storage in terms of source term calculation, criticality, dose rate and thermal calculation [5]. Some studies have been conducted for investigating radionuclide characteristics of HTR-10 however it is limited only about the inventory activity [6,7]. Radionuclide activity is important in assessing the performance of spent fuel in geological disposal [8]. Thermal power quantification of spent fuel is used as the basis for safety analysis of heat removal in the spent fuel storage tank $[9,10]$. Neutron production and photon release rates are also crucial for shielding analysis of spent fuel cask [11, 12]. In this study, the investigation of radionuclide characteristics was performed using ORIGEN2.1 code, a well-known and widely used computer code for the analysis of spent fuel composition and radiological characteristics necessary for nuclear facility design and safety analysis [13]. Using ORIGEN2.1, one fuel pebble was simulated to be irradiated in the core during 5 cycles with 40 days decaytime at the end of each cycle. After completing all cycles, the pebble was then decayed for 5 years. The radionuclide characteristics at the end of cycle and during the first 5 years cooling time are discussed in this paper.

\section{THEORY}

ORIGEN2.1 is a versatile fuel depletion and radioactive decay computer code for simulating fuel cycles and calculating several important characteristics of nuclear material such as nuclide composition, radioactivity, toxicity, neutron emission and photon emission. Calculation method used in ORIGEN2.1 is based on an ordinary differential equation which is represented the buildup and decay process of radionuclides as follows[14]:

$$
\frac{d X_{i}}{d t}=\sum_{j=1}^{N} l_{i j} \lambda_{j} X_{j}+\varphi \sum_{k=1}^{N} f_{i k} \sigma_{k} X_{k}-\left(\lambda_{i}+\varphi \sigma_{i}+r_{i}\right) X_{i}+F_{i}, \quad i=1, \ldots \ldots, N
$$

Where $X_{i}$ is the density of nuclide $i, N$ is the number of nuclide, $l_{i j}$ is fraction of radioactive disintegration by other nuclide, which lead to formation of species $i, j$ is the number of iteration starting from $j=1$ through $j=N, \varphi$ is position- and energy-averaged neutron flux, $f_{i k}$ is fraction of neutron absorption by other nuclides, which lead to formation of speciesi, $\sigma_{\mathrm{k}}$ is spectrum-averaged neutron absorption cross section of nuclide $k, r_{i}$ is continuous removal rate of nuclide $i$ from the system, and $F_{i}$ is continuous feed rate of nuclide $i$. 
By solving this equation to obtain the composition of each nuclide, another characteristic such as radioactivity will be calculated based on the radionuclide concentration. In order to solve this equation, the radioactive decay, photon emission, and neutron cross section library are required. In this work, neutron cross section library used is the the library for high temperature reactor type [15]. The thermal power, neutron production, and photon release rates were calculated based on these libraries. In the output of ORIGEN2.1 simulation, the radionuclides are divided into three groups which are activation products (720 nuclides), fission products (850 nuclides), and actinides (130 nuclides).

\section{METHODOLOGY}

The radionuclide characteristics were calculated through ORIGEN2.1 simulation. The reactor parameters used as the input for ORIGEN2.1 simulation are shown in Table 1.

Table 1. Parameters of HTR-10 [16]

\begin{tabular}{clc}
\hline No & \multicolumn{1}{c}{ Parameters } & Value \\
\hline 1 & Thermal power & $10 \mathrm{MW}$ \\
2 & Fuel kernel type & $\mathrm{UO}_{2}$ \\
3 & Heavy metal loading per pebble & $5 \mathrm{grams}$ \\
4 & U-235 enrichment & $17 \%$ \\
5 & Fuel kernel coating & $\mathrm{IPyC}, \mathrm{SiC}, \mathrm{OPyC}$ \\
6 & Thickness of IPyC/SiC/OPyC & $0.004 / 0.0035 / 0.004 \mathrm{~cm}$ \\
7 & Density of IPyC/SiC/OPyC & $1.9 / 3.18 / 1.9$ \\
8 & Mass of one pebble & 200 grams \\
9 & Number of fuel in equilibrium state & 27000 pebbles \\
10 & Fuel loading scheme & Multipass $(5 \mathrm{cycles})$ \\
11 & Total fuel residence time & 1080 days \\
\hline
\end{tabular}

The detail composition of each isotope in $\mathrm{UO}_{2}$ was determined based on the heavy metal loading per pebble and U-235 enrichment and those compositions are shown in Table 2.

Table 2. Material composition for the input of ORIGEN2.1

\begin{tabular}{ccc}
\hline No & Isotope & Composition (grams) \\
\hline 1 & U-234 & 0.84953 \\
2 & U-235 & 0.84953 \\
3 & U-238 & 4.14618 \\
4 & O-16 & 0.67334 \\
5 & C-12 & 195.6738 \\
6 & Si-28 & 1.28956 \\
\hline
\end{tabular}

In performing ORIGEN2.1 simulation, one pebble was assumed to be irradiated by an average specific power of $3.7 \times 10^{-4} \mathrm{MW}$, which was calculated based on the thermal output of RDE (10 MW) divided by the number of pebbles (27000 pebbles). The irradiation scenario was assumed based on the loading scheme of the pebble fuel. Since the total of irradiation time is about 1080 for 5 cycles, it was assumed that a pebble takes 216 days for each cycle. Before the burnup measurement process takes place for each pebble, around 5000 pebbles are piled up in a discharge tube waiting for its turn for burnup measurement. Since there are 125 pebbles performing burnup in each day, it means that each pebble is waiting in the discharge tube for about 40 days[17]. This decay period was also taken into account in the ORIGEN2.1 simulation. After completing the 5 cycles of irradiation, the pebble was then decayed for 5 years as a representation for cooling period in the spent fuel storage. 


\section{RESULTS AND DISCUSSION}

The results for total radionuclide activities of one pebble fuel from the beginning of cycle until the end of cycle are shown in Figure 1.These total activities are the contribution of all activation products (AP), actinides and daughters (AD), and fission products (FP). Some sharp activity reductions occurred at the end of each cycle indicate the 40 days cooling period when the pebble fuel piled up in the discharged tube before performing burnup measurement. During this cooling periode, almost all of short-lived radionuclides vanish due to decay process, such as U-239, $\mathrm{Pu}-241$, some isotopes of $\mathrm{Kr}, \mathrm{Br}, \mathrm{Sr}, \mathrm{Rb}, \mathrm{I}, \mathrm{Cs}, \mathrm{Xe}, \mathrm{Te}, \mathrm{Ba}, \mathrm{Pd}, \mathrm{Ag}, \mathrm{Sm}$, and etc.The medium- and long-lived radionuclides that remain in the pebble fuel and have significant activity at the end of cycle are shown in Table 3. Due to the excessive output data produced from ORIGEN2.1, the data shown in Table 3 is only the important radionuclides or whose activity is higher than the cut-off value of $1.00 \mathrm{E}-05$.

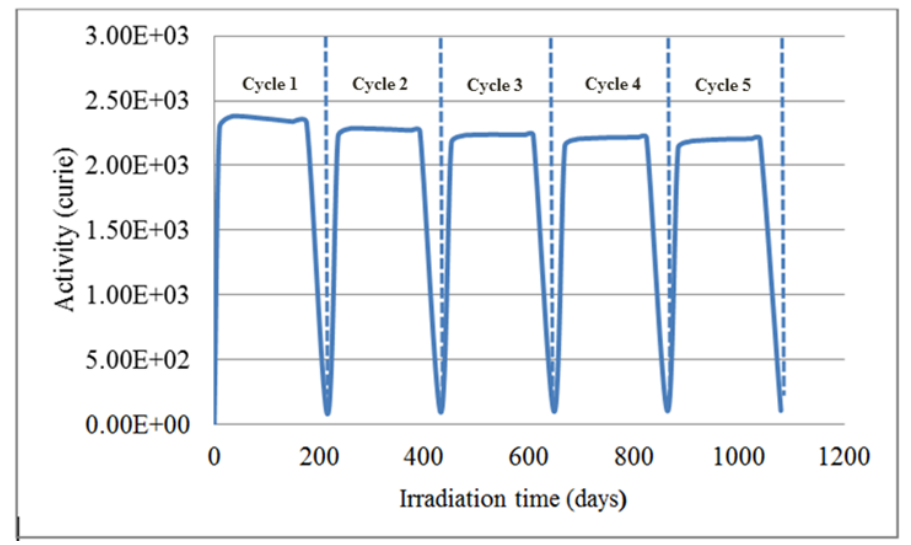

Figure 1. Total activity of one pebble fuel from the beginning to the end of cycle

Table 3. Radionuclide activity inside the pebble at the end of cycle

\begin{tabular}{|c|c|c|c|c|c|}
\hline \multicolumn{2}{|c|}{ Activation Products (Ci) } & \multicolumn{4}{|c|}{ Fission Products $(\mathrm{Ci})$} \\
\hline $\mathrm{H}-3$ & $1.93 \mathrm{E}-05$ & $\mathrm{Kr}-85$ & $9.51 \mathrm{E}-02$ & Te-129 & $1.30 \mathrm{E}-01$ \\
\hline BE-10 & $1.99 \mathrm{E}-07$ & $\mathrm{Rb}-86$ & $1.28 \mathrm{E}-03$ & $\mathrm{I}-131$ & $3.23 \mathrm{E}-01$ \\
\hline C-14 & 7.42E-06 & Sr-89 & $5.52 \mathrm{E}+00$ & Te-132 & $2.85 \mathrm{E}-03$ \\
\hline $\mathrm{P}-32$ & $2.80 \mathrm{E}-07$ & Sr-90 & $7.59 \mathrm{E}-01$ & $\mathrm{I}-132$ & $2.94 \mathrm{E}-03$ \\
\hline \multicolumn{2}{|c|}{ Actinides $(\mathrm{Ci})$} & Zr-95 & $1.04 \mathrm{E}+01$ & $\mathrm{Xe}-133$ & $1.23 \mathrm{E}-01$ \\
\hline U-234 & 7.67E-06 & Y-90 & $7.59 \mathrm{E}-01$ & Cs-134 & $6.35 \mathrm{E}-01$ \\
\hline $\mathrm{U}-235$ & $1.23 \mathrm{E}-06$ & Y-91 & $7.57 \mathrm{E}+00$ & Cs-136 & 4.17E-02 \\
\hline $\mathrm{U}-237$ & $7.88 \mathrm{E}-02$ & Zr-95 & $1.04 \mathrm{E}+01$ & Cs-137 & $1.03 \mathrm{E}+00$ \\
\hline U-238 & $1.30 \mathrm{E}-06$ & $\mathrm{Nb}-95$ & $1.39 \mathrm{E}+01$ & Ce-141 & $7.18 \mathrm{E}+00$ \\
\hline $\mathrm{Np}-238$ & $2.39 \mathrm{E}-06$ & $\mathrm{Ru}-103$ & $7.23 \mathrm{E}+00$ & Ba-140 & $2.04 \mathrm{E}+00$ \\
\hline $\mathrm{Np}-239$ & $1.91 \mathrm{E}-03$ & Rh-103m & $6.52 \mathrm{E}+00$ & La-140 & $2.35 \mathrm{E}+00$ \\
\hline $\mathrm{Pu}-238$ & $7.80 \mathrm{E}-03$ & Ru-106 & $4.18 \mathrm{E}+00$ & $\mathrm{Ce}-141$ & $7.18 \mathrm{E}+00$ \\
\hline $\mathrm{Pu}-239$ & $8.18 \mathrm{E}-03$ & Rh-106 & $4.18 \mathrm{E}+00$ & Pr-143 & $2.21 \mathrm{E}+00$ \\
\hline $\mathrm{Pu}-240$ & $7.15 \mathrm{E}-03$ & Ag110 & $1.90 \mathrm{E}-04$ & Ce-144 & $1.04 \mathrm{E}+01$ \\
\hline $\mathrm{Pu}-241$ & $2.37 \mathrm{E}+00$ & $\mathrm{Ag} 110 \mathrm{M}$ & $1.43 \mathrm{E}-02$ & Pr-144 & $1.04 \mathrm{E}+01$ \\
\hline $\mathrm{Pu}-242$ & $9.86 \mathrm{E}-06$ & Ag-111 & $1.29 \mathrm{E}-02$ & Nd-147 & $5.40 \mathrm{E}-01$ \\
\hline Am-241 & $3.23 \mathrm{E}-03$ & Sn-123 & $1.76 \mathrm{E}-02$ & Pm-147 & $2.24 \mathrm{E}+00$ \\
\hline Am-242 & $1.32 \mathrm{E}-04$ & Sb-124 & $2.446 \mathrm{E}-03$ & Sm-151 & $1.13 \mathrm{E}-02$ \\
\hline $\mathrm{Cm}-242$ & $3.02 \mathrm{E}-01$ & Te-127 & $9.207 \mathrm{E}-02$ & Eu-154 & $4.02 \mathrm{E}-02$ \\
\hline
\end{tabular}

Total Activity $(\mathrm{AP}+\mathrm{AD}+\mathrm{FP})=106.2 \mathrm{Ci}$ 
The radionuclides in Table 3 are categorized into three groups; activation products, actinides, and fission products. Activation products in RDE spent fuel come from neutron capture reaction of graphite, fuel kernel coatings, and oxygen in the $\mathrm{UO}_{2}$. The presence of $\mathrm{C}-14$ in Table 3 comes from neutron irradiation of graphite [18], the presence of H-3 comes from several sources, one of which is from ternary fission of the fuel [19]. Most of activation products are short-lived radionuclides so that in the RDE spent fuel, the remaining significant activation products are only $\mathrm{H}-3, \mathrm{Be}-10, \mathrm{C}-14$, and P-32 with half-life of 12.4 years, $1.3 \mathrm{E}+06$ years, $5.7 \mathrm{E}+03$ years, and 14.29 days, respectively.

Actinides in the RDE spent fuel are originated from the fuel itself, which are the transmutation products of uranium and the products of other actinide decay chain. Most of the actinides are long-lived radionuclides with half-life in the order of million years in average. Among all the actinides, $\mathrm{Pu}-241$, whose halflife is 14 years, has the highest activity which is approximately 2.37 curies.

Fission products in the RDE spent fuel are produced from fission reaction of the fuel. The halflife of fission products is ranging from short- to medium lifetime. At the end of cycle of the pebble fuel, there are still many fission products remaining in the fuel with very significant activity. The total activity of RDE spent fuel is mainly contributed by these fission products. The highest activity is owned by Y-91. Fission products that have significant impact to human health are the isotope of Sr, I, and Cs. From Table 3, the activity of Sr-89 is extremely high (5.52 curies). The activity of Cs-137 is also very high and this usually becomes a great concern since the half-life of Cs-137 quite long which is around 30.7 years.

The total activity of one RDE spent pebble fuel contributed by all of the activation products, actinides, and fission products is approximately 106.2 curies. In relation to the handling process of spent fuel, there are thousands of spent pebbles that have to be managed and moved into the spent fuel storage, so that the total activity of 106.2 curies from one spent pebble will be multiplied by the number of all spent fuel stored in the storage tank. This activity data can be used as a sourceterm for permorming safety analysis of the spent fuel storage tank.

The results for thermal power produced by one RDE spent fuel are shown in Table 4. This thermal power comes from the decay process of all radionuclides inside the spent fuel and this is usually called as decay heat. The total thermal power of one spent fuel is about 0.413 watts. The data of thermal power can be used for determining the heat removal mechanism that has to be applied in the spent fuel storage tank.

Table 4. Thermal power of one pebble fuel at the end of cycle

\begin{tabular}{cc}
\hline Nuclides & Thermal Power (Watts) \\
\hline Activation products & $5.90 \mathrm{E}-09$ \\
Actinides & $1.23 \mathrm{E}-02$ \\
Fission Products & $4.01 \mathrm{E}-01$ \\
Total & $4.13 \mathrm{E}-01$ \\
\hline
\end{tabular}

The results for neutron production rates are shown in Table 5. There are two types of neutron production mechanism calculated by ORIGEN2.1, which are $(\alpha, n)$ reaction and spontaneous fission reaction. Cm-242 produces the biggest number of neutron from spontaneous fission reaction. The total neutron produced from one spent fuel is approximately $2.65 \mathrm{E}+03$ neutrons per second. The design of spent fuel storage tank should consider this neutron rates data in order to determine the appropriate material type and configuration used for neutron shielding. 
Table 5. Neutron production rates (neutrons/sec) in one pebble fuel at the end of cycle

\begin{tabular}{cccc}
\hline Radionuclides & $\begin{array}{c}\text { Neutron production } \\
\text { from }(\alpha, \mathrm{n}) \text { reaction }\end{array}$ & Radionuclides & $\begin{array}{c}\text { Neutron production } \\
\text { from spontaneous } \\
\text { fission }\end{array}$ \\
\hline $\mathrm{Pu}-238$ & $7.42 \mathrm{E}+00$ & $\mathrm{Pu}-240$ & $2.86 \mathrm{E}+01$ \\
$\mathrm{Pu}-239$ & $5.96 \mathrm{E}+00$ & $\mathrm{Pu}-242$ & $4.35 \mathrm{E}+00$ \\
$\mathrm{Pu}-240$ & $5.42 \mathrm{E}+00$ & $\mathrm{Cm}-242$ & $1.97 \mathrm{E}+03$ \\
$\mathrm{Am}-241$ & $3.10 \mathrm{E}+00$ & $\mathrm{Cm}-244$ & $2.15 \mathrm{E}+02$ \\
$\mathrm{Cm}-242$ & $4.06 \mathrm{E}+02$ & \\
$\mathrm{Cm}-244$ & $1.78 \mathrm{E}+00$ & \\
\hline & Total: $\mathbf{2 . 6 5 E}+\mathbf{0 3}$ neutrons/sec
\end{tabular}

The results for photon release rates are shown in Table 6. ORIGEN2.1 produces data for photon release rates in 18 groups of energy, ranging from $0.01 \mathrm{MeV}$ to $9.5 \mathrm{MeV}$. These photons are mostly gamma radiation produced from the decay of radionuclides inside the spent fuel. From Table 6 , it is shown that the total photon rate from all activation products, actinides, and fission products is approximately $3.27 \mathrm{E}+12$ photons per second. The quantification of photon rate along with its energy, besides as a basis for shielding design, is also used as an input data for calculating biological shielding in the vicinity of the spent fuel storage tank. This biological radiation dose rate determines the working mechanism of the workers around the spent fuel tank.

Table 6. Photon release rates in one spent fuel at the end of cycle

\begin{tabular}{cccc}
\hline \multirow{2}{*}{ Energy mean $(\mathrm{MeV})$} & \multicolumn{3}{c}{ Photon release rate (photons/sec) } \\
& Activation products & Actinides & Fission Products \\
\hline $1.00 \mathrm{E}-02$ & $1.18 \mathrm{E}+04$ & $4.50 \mathrm{E}+09$ & $7.79 \mathrm{E}+11$ \\
$2.50 \mathrm{E}-02$ & $1.96 \mathrm{E}+03$ & $9.43 \mathrm{E}+07$ & $1.96 \mathrm{E}+11$ \\
$3.75 \mathrm{E}-02$ & $1.12 \mathrm{E}+03$ & $1.82 \mathrm{E}+07$ & $2.08 \mathrm{E}+11$ \\
$5.75 \mathrm{E}-02$ & $1.33 \mathrm{E}+03$ & $1.19 \mathrm{E}+09$ & $1.50 \mathrm{E}+11$ \\
$8.50 \mathrm{E}-02$ & $6.33 \mathrm{E}+02$ & $5.44 \mathrm{E}+08$ & $1.08 \mathrm{E}+11$ \\
$1.25 \mathrm{E}-01$ & $3.71 \mathrm{E}+02$ & $9.59 \mathrm{E}+08$ & $2.53 \mathrm{E}+11$ \\
$2.25 \mathrm{E}-01$ & $4.67 \mathrm{E}+02$ & $7.21 \mathrm{E}+08$ & $9.04 \mathrm{E}+10$ \\
$3.75 \mathrm{E}-01$ & $1.82 \mathrm{E}+02$ & $4.34 \mathrm{E}+07$ & $7.57 \mathrm{E}+10$ \\
$5.75 \mathrm{E}-01$ & $7.69 \mathrm{E}+01$ & $4.16 \mathrm{E}+04$ & $4.34 \mathrm{E}+11$ \\
$8.50 \mathrm{E}-01$ & $1.60 \mathrm{E}+01$ & $3.70 \mathrm{E}+04$ & $8.71 \mathrm{E}+11$ \\
$1.25 \mathrm{E}+00$ & $2.16 \mathrm{E}+00$ & $2.08 \mathrm{E}+04$ & $1.44 \mathrm{E}+10$ \\
$1.75 \mathrm{E}+00$ & $3.51 \mathrm{E}-03$ & $8.60 \mathrm{E}+02$ & $7.73 \mathrm{E}+10$ \\
$2.25 \mathrm{E}+00$ & $4.11 \mathrm{E}-22$ & $4.69 \mathrm{E}+02$ & $4.44 \mathrm{E}+09$ \\
$2.75 \mathrm{E}+00$ & $1.47 \mathrm{E}-19$ & $3.06 \mathrm{E}+02$ & $2.92 \mathrm{E}+09$ \\
$3.50 \mathrm{E}+00$ & $1.01 \mathrm{E}-22$ & $2.44 \mathrm{E}+02$ & $2.81 \mathrm{E}+07$ \\
$5.00 \mathrm{E}+00$ & $1.05 \mathrm{E}-24$ & $1.04 \mathrm{E}+02$ & $5.73 \mathrm{E}-10$ \\
$7.00 \mathrm{E}+00$ & $0.00 \mathrm{E}+00$ & $1.20 \mathrm{E}+01$ & $3.72 \mathrm{E}-11$ \\
$9.50 \mathrm{E}+00$ & $0.00 \mathrm{E}+00$ & $1.38 \mathrm{E}+00$ & $2.35 \mathrm{E}-12$ \\
\hline Total & $\mathbf{1 . 7 9 E}+\mathbf{0 4}$ & $\mathbf{8 . 0 6 8 E}+\mathbf{0 9}$ & $\mathbf{3 . 2 6 5 E}+\mathbf{1 2}$ \\
\hline & & &
\end{tabular}

The characteristics of radionuclides inside the RDE spent fuels change over the times due to the decay process of the radionuclides. In general, the total concentration of the radionuclides and its radiation characteristics are decreasing. The summary of radionuclides characteristics inside one 
spent fuel from the fisrt time it is discharged out of the core until the first 5 years cooling period in the spent fuel storage are shown in Table 7. From Table 7 it is shown that the total activity, neutron and photon ratesare decreasing drastically at the first year. It means that the majority of radionuclides inside the spent fuel are the medium-lived radionuclides whose half-life are within days or less that 1 year. After the first year cooling period, the total activity, neutron and photon rates are slowly decreasing. On the other hand, the thermal powers are slowly decreasing at the first year and tend to be constant after that until the fifth year.

Table 7. The radionuclides characteristics at the end of cycle until 5 years cooling time in the spent fuel storage

\begin{tabular}{lcccccc}
\hline \multicolumn{1}{c}{$\begin{array}{c}\text { Radionuclides } \\
\text { characteritics }\end{array}$} & \multicolumn{7}{c}{ Time (years) } \\
\cline { 2 - 7 } & $\begin{array}{c}\text { At the end } \\
\text { of } 5 \text { cycles }\end{array}$ & 1 & 2 & 3 & 4 & 5 \\
\cline { 1 - 6 } $\begin{array}{l}\text { Total activity (Ci) } \\
1.06 \mathrm{E}+02\end{array}$ & $2.19 \mathrm{E}+01$ & $1.31 \mathrm{E}+01$ & $9.34 \mathrm{E}+00$ & $7.46 \mathrm{E}+00$ & $6.43 \mathrm{E}+00$ \\
$\begin{array}{l}\text { Neutron rate } \\
\text { (neutrons/second) }\end{array}$ & $2.65 \mathrm{E}+03$ & $7.73 \mathrm{E}+02$ & $3.73 \mathrm{E}+02$ & $2.84 \mathrm{E}+02$ & $2.62 \mathrm{E}+02$ & $2.54 \mathrm{E}+02$ \\
$\begin{array}{l}\text { Photon rate } \\
\text { (photons/second) }\end{array}$ & $1.79 \mathrm{E}+04$ & $9.76 \mathrm{E}+03$ & $9.74 \mathrm{E}+03$ & $9.73 \mathrm{E}+03$ & $9.72 \mathrm{E}+03$ & $9.70 \mathrm{E}+03$ \\
$\begin{array}{l}\text { Thermal power } \\
\text { (watts) }\end{array}$ & $5.90 \mathrm{E}-09$ & $3.03 \mathrm{E}-09$ & $2.99 \mathrm{E}-09$ & $2.96 \mathrm{E}-09$ & $2.93 \mathrm{E}-09$ & $2.90 \mathrm{E}-09$ \\
\hline
\end{tabular}

\section{CONCLUSION}

The radionuclides characteristics of RDE spent fuel at the end of cycle and after five years cooling time in spent fuel storage were investigated using ORIGEN2.1 code. Those charateristics, which are radionuclide activity, thermal power, neutron production, and photon release rates, are very important for evaluating the safety of fuel handling system and spent fuel storage tank. The result for total activity of all radionuclides of one spent fuel at the end of cycle is approximately 106.2 curies. This total activity is the contribution of the activation products, actinides, and fission products, however some important radionuclides that have significant activity are Sr-89, Cs-137, and I-131 with the activity of $5.52 \mathrm{Ci}, 1.03 \mathrm{Ci}$, and $0.32 \mathrm{Ci}$, respectively. The total thermal power of one spent fuel at the end of 5 cycles is approximately 0.41 watts. This thermal power is the heat produced from the radionuclides decay of spent fuel. The results for total neutron production rate and photon release rate are approximately $2.65 \mathrm{E}+03$ neutrons/second and $3.27 \mathrm{E}+12$ photons/second, respectively. After five years cooling time in the spent fuel storage, the total activity of radionuclides is rapidly decreasing during the first year, which shows that the majority of short- and medium-lived radionuclides vanish due to the decay process while the long-lived radionuclides remain in the spent fuel. The same trend occurs in the thermal, neutron, and photon release characteristics. After the rapid decreasing in the first year of cooling time, the thermal, neutron, and photon release characteristics are nearly constant until the fifth year of cooling time.

\section{ACKNOWLEDGEMENT}

The works are conducted under the government reseach and funding managed by Center for Nuclear Reactor Technology and Safety (PTKRN), BATAN, for the year of 2017. The study is also partially supported by 2018 National Research Insentive RISTEK-DIKTI. 


\section{REFERENCES}

1. Tjahjono H. Investigation of RDE thermal parameters changes in response to long-term station black out. Tri Dasa Mega. 2017. 19(2):83-92.

2. Sabharwall P., Bragg-sitton S.M., Stoots C. Challenges in the development of high temperature reactors. Energy Convers. Manag. 2013. 74:574-81.

3. Setiadipura T., Irwanto D. Preliminary Neutronic Design of High Burnup OTTO Cycle Pebble Bed Reactor. Atom Indonesia. 2015. 41(1):7-15.

4. Zhang Z., Yu S. Future HTGR developments in China after the criticality of the HTR-10. Nucl. Eng. Des. 2002. 218:249-57.

5. Palacio A. Design process for dual-purpose nuclear spent fuel casks. Energy Procedia. 2017. 127(2016):398-406.

6. Kuntjoro S., Udiyani P.M. Analisis inventory Reaktor Daya Eksperimental Jenis Reaktor Gas Temperatur Tinggi. Urania. 2016. 22:53-64.

7. Jeong H., Chang S.H. Development of a method of evaluating an inventory of fission products for a pebble bed reactor. Ann. Nucl. Energy. 2008. 35(12):2161-71.

8. Johnson L., Poinssot C., Lovera P. Spent fuel radionuclide source-term model for assessing spent fuel performance in geological disposal . Part I: Assessment of the instant release fraction. J. Nucl. Mater. 2005. 346:56-65.

9. Fuls W.F., Mathews E.H. Passive cooling of the PBMR spent and used fuel tanks. Nucl. Eng. Des. 2007. 237:1354-62.

10. Jin-hua W., Yi-fan H., Yong T., Bin W.U. Natural safety analysis of the spent fuel residual heat removal in loading and storage process of HTR-10. Energy Procedia. 2013. 39:227-39.

11. Ko J., Park J., Jung I., Lee G., Baeg C., Kim T. Shielding analysis of dual purpose casks for spent nuclear fuel under normal storage conditions. Nucl. Eng. Technol. 2014. 46(4):547-56.

12. Mohammadi A., Hassanzadeh M., Gharib M. Shielding calculation and criticality safety analysis of spent fuel transportation cask in Reseacrh Reactors. Appl. Radiat. Isot. 2015.

13. Mertyurek U., Gauld I.C. Development of ORIGEN libraries for Mixed Oxide ( MOX ) fuel assembly designs. Nucl. Eng. Des. 2016. 297:220-30.

14. Husnayani I., Kuntjoro S., Udiyani P.M. Fission products inventory analysis of HTGR fuel. in: Seminar Nasional Teknologi Energi Nuklir. Batam. 2016.

15. Diecker J. Development of a High Temperature Gas-Cooled Reactor TRISOcoated ....Massachusetts Institute of Technology; 2005.

16. Tang C., Fu X., Zhu J., Zhao H., Tang Y. Comparison of two irradiation testing results of HTR-10 fuel spheres. Nucl. Eng. Des. 2012. 251:453-8.

17. Huang P., Liang X., Chen X. The operation characteristics of the fuel handling system of HTR-10. in: International Conference on Nuclear Engineering. China. 2010. pp. 1-7.

18. Li H., Liu X., Xie F., Jia F. Experimental study on the content and distribution of key nuclides in an irradiated graphite sphere of HTR-10. Nucl. Eng. Des. 2017. 323(March):39-45.

19. Fernando F., Simões L., Duarte A., Aguiar S., Marcelo C., Lapa F., et al. Advanced nuclear reactors and tritium impacts. Modeling the aquatic pathway. Prog. Nucl. Energy. 2013. 69:9-22. 